\title{
Miranda
}

Revue pluridisciplinaire du monde anglophone /

Multidisciplinary peer-reviewed journal on the English-

speaking world

$17 \mid 2018$

Paysages et héritages de David Bowie

\section{Geography and Plays (1922) : paysages intimes}

\section{Emeline Jouve}

\section{(2) OpenEdition}

\section{Journals}

Édition électronique

URL : http://journals.openedition.org/miranda/15605

DOI : 10.4000/miranda.15605

ISSN : 2108-6559

Éditeur

Université Toulouse - Jean Jaurès

\section{Référence électronique}

Emeline Jouve, "Geography and Plays (1922) : paysages intimes », Miranda [En ligne], 17 | 2018, mis en ligne le 03 octobre 2018, consulté le 16 février 2021. URL : http://journals.openedition.org/miranda/ 15605 ; DOI : https://doi.org/10.4000/miranda.15605

Ce document a été généré automatiquement le 16 février 2021.

\section{c) $8 \odot$}

Miranda is licensed under a Creative Commons Attribution-NonCommercial-NoDerivatives 4.0 International License. 


\title{
Geography and Plays (1922) : paysages intimes
}

\author{
Emeline Jouve
}

1 «Annus mirabilis » du modernisme, 1922 est célébrée pour les parutions de Ulysses de James Joyce ou de The Waste Land de T.S. Eliot, emblèmes de révolutions formelles romanesques et poétiques du début du siècle dernier. Afin de rendre hommage aux expérimentations dramatiques de Gertrude Stein injustement négligées par la critique, il conviendrait d'ajouter à la liste des publications fameuses de cette année 1922 celle de Geography and Plays. Ce recueil est composé de diverses formes courtes dont des pièces de théâtre écrites entre 1913 et 1919. Ces œuvres dramatiques de l'auteure américaine sont, à l'instar des œuvres de Joyce et Eliot, marquées du sceau révolutionnaire en cela qu'elles déjouent les règles formelles du drame dont elles se jouent pour ainsi créer un nouvel espace de je(u), le théâtre "d'une expérience individuelle». En tant que "produit d'une expérience individuelle sensible», "élaboration esthétique singulière », ces pièces de jeunesse de Stein font paysage (Collot, « D'une modernité plurielle »17). ${ }^{1}$

2 Si comme l'écrit Margaret Dickie, l'œuvre de Stein a souvent été étudiée dans son rapport au temps, la notion d'espace, peu considérée par la critique, est primordiale pour cerner les enjeux de l'écriture de l'artiste et en particulier de son écriture dramatique. ${ }^{2}$ Par le truchement de la conjonction de coordination "and", Stein rend compte dans le titre de son recueil du lien étroit, bien qu'ambigu, que l'écriture dramatique, « plays », entretient avec l'espace, " geography ». À partir des années 1920, Stein se mit à composer ce qu'elle appela des « pièces paysages », un concept sur lequel elle revint dans son discours « Plays » prononcé en 1934 à l'occasion de sa tournée de conférences aux États-Unis, et au cours duquel elle explique que pour elle « une pièce [est] exactement comme un paysage » (traduction de l'auteur). ${ }^{3}$ Stein fit l'expérience de cette épiphanie alors qu'elle admirait la campagne environnante de Bilignin, dans l'Ain, où elle séjournait avec son amie Alice B. Toklas. Cet évènement peut se lire comme une illustration de ce que Michel Collot nomme la "pensée-paysage ", un syntagme qui rend compte «à la fois que le paysage donne à penser, et que la pensée se déploie 
comme un paysage » (Pensée-Paysage 12). L'image du site perçu par Stein lui inspira, réflexivement, au gré du déploiement des flux de conscience, un paysage dramatique et dramaturgique. ${ }^{4}$

3 Si pour Gertrude Stein, Lend a Hand or Four Religions, achevée en cette même fameuse année de 1922, fut sa première "landscape play » ou "pièce paysage » (Stein in Ryan 60), les pièces de Geography and Plays (écrites avant 1922 et la publication du volume) peuvent être considérées comme des prototypes du paysagisme dramatique steinien. ${ }^{5}$ Ces pièces se lisent comme des paysages intimes pluriels en cela qu'elles retranscrivent les subjectivités d'une auteure, de ses personnages fantasmatiques mais aussi des lectrices et lecteurs. Afin de rendre compte de cette subjectivité, nous reviendrons sur l'emploi des termes "géographie » et "paysage " par Stein avant de considérer les ressorts de l'écriture picturale steinienne. Enfin, l'agentivité des lecteurs-spectateurs sera abordée.

4 Notre étude du drame paysage est basée sur l'analyse des vingt et une pièces rassemblées dans Geography and Plays : « One (Van Vechten)» (1913), « IIIIIIIII » (1913), «A Curtain Raiser» (1913), «White Wines. Three Acts» (1913), « What Happened. A Play in Five Acts» (1913), « Not Sightly. A Play» (1914), «He Said It. Monologue» (1915), «Ladies Voices (Curtain Raiser)» (1916), « Polybe in Port. A Curtain Raiser » (1916), « Do Let Us Go Away. A Play » (1916), « Turkey Bones and Eating and We Liked It. A Play » (1916), «Please Do Not Suffer. A Play » (1916), « Mexico. A Play » (1916), « I Like It to Be a Play. A Play» (1916), «For the Country Entirely. A Play in Letters » (1916), «Every Afternoon. A Dialogue " (1916), «Captain Walter Arnold. A Play» (1916), « Bonne Annee. A Play (1916), « Counting her Dresses. A Play» (1917), « The King or Something (The Public is Invited to Dance)» (1917), «Accent in Alsace. A Reasonable Tragedy» (1919). Afin d'illustrer mes arguments, seuls quelques exemples seront convoqués au cours de mon étude qui ne prétend pas à une analyse exhaustive des vingt et une pièces. ${ }^{6}$

\section{De la géographie au paysage}

5 Pour Gertrude Stein, une pièce n'est pas un paysage mais comme un paysage. La comparaison induit que les deux notions partagent des valeurs communes mais que chacune a son identité propre qui la distingue de l'autre. Ainsi, le paysage-drame est chez Stein un drame de ce qui est comme un paysage et non un drame du paysage dans le sens d'étendue spatiale. Les paysages en tant que représentation d'un environnement naturel ou construit semblent ne pas (ou très peu) avoir leur place dans les pièces $d u$ recueil Geography and Plays. Si Stein fait référence dans ses pièces à des "lieux " qui marquent "une forte délimitation topographique et culturelle» (Collot, "D'une modernité plurielle », 16), elle « localise et délocalise » simultanément les espaces où se jouent les drames comme Margaret Dickie le souligne (traduction de l'auteur; 70). ${ }^{7}$ L'abondance floue de ces références spatiales semble en contradiction avec le concept de "géographie » introduit dans le titre qui renvoie donc à un espace objectivement délimité et donc clairement identifié alors que les espaces mentionnés dans les pièces ne sont pas délimités puisqu'ils sont évoqués puis niés. Avec l'emploi de " géographie » dès le paratexte liminal, Stein joue avec les horizons d'attente de son lectorat qui, une fois le seuil de la fiction franchi, découvre que la géographie n'est pas au cœur de l'œuvre et que le terme scientifique du titre masque en fait l'importance de ce « qui fait 
paysage » dans le recueil, c'est-à-dire la notion de point de vue. Pour Michel Collot et Maurice Merleau-Ponty avant lui, la géographie est au paysage ce que le factuel est au sensible. Le paysage n'existe qu'à travers le regard d'un sujet, sujet que la géographie nie au nom de l'objectivité :

À la différence de la connaissance scientifique, qui se veut objective, cette pensée que la phénoménologie décèle dans l'expérience sensible est de l'ordre d'une « connaissance au monde de soi-même »... De cet ancrage perceptif et subjectif, le paysage témoigne : il n'est pas le pays, mais un aspect du pays tel qu'il se présente au regard d'un observateur. Il se distingue ainsi de l'étendue, objective, géométrique ou géographique. À la différence de l'espace de la carte, qui n'est vu de nulle part, c'est un espace perçu et donc irréductiblement subjectif (La penséepaysage 27-28).

Chez Stein, le sujet est au cœur du drame. L'auteure met en scène des «espaces perçus ». Cet espace, dans l'acception métaphorique du terme, existe tout justement car il est "perçu» par un sujet: il est donc ce "produit d'expérience individuelle, sensible» (Collot, «D’une modernité plurielle»17). Au début du passage intitulé "Another Act » de la pièce "Accents in Alsace ", une voix-personnage anonyme rend compte de la prééminence de la perception subjective de l'objet regardé par le sujet sur l'objet lui-même, un «nuage » dans l'exemple qui suit :

Another Act

Clouds do not fatten with teaching.

They do not fatten at all.

We wonder if it is influenced

By the way I guess (411).

7 La césure après « influenced » crée un effet de suspens : la réplique est alors suspendue dans les airs avant que le personnage ne coupe court à l'attente du lecteur/spectateur en mettant alors en exergue sa propre subjectivité. Le nuage ne grossit pas parce que c'est ainsi que le sujet regardant croit voir la chose ("I guess"). Le mode de perception est celui de l'abstraction, de l'association d'idées (dans l'acception psychologique du terme) comme l'illustre la personnification du paysage. ${ }^{8}$ La présence de la première personne du pluriel, «we », qui précède le «I », rend compte de la multiplication des points de vue qui abondent en effet dans les pièces de Stein. L'abstraction et la démultiplication des points de vue rappellent (et nous y reviendrons dans la deuxième partie) le travail des peintres surréalistes et cubistes dont Stein collectionnait les œuvres. Comme ces peintres, l'auteure rompt avec la tradition de la mimesis. L'objet perçu n'est pas figuré mais défiguré, mis en pièces par la subjectivité du sujetpersonnage qui livre ainsi sa perception reconfigurée de la réalité. L'accent sur l'espace $\mathrm{vu}$, perçu, plutôt que sur l'espace scientifiquement repéré illustre bien le fait que Stein présente dans ses pièces des « lieux-paysages » et non des « lieux-géographie ».

8 Stein déconstruit la géographie au niveau littéral mais aussi au niveau métalittéraire. En effet, Stein joue avec les genres littéraires et s'amuse avec la géographie de la littérature pour faire voler en éclats les frontières entre les genres. Les textes dramatiques apparaissent sous formes hybrides. Dans « For the Country Entirely. A Play in Letters " Stein croise la forme épistolaire et une forme dramatique reconfigurée puisque la division traditionnelle en actes et scènes devient une division en chapitres comme dans un roman.

9 FOR THE COUNTRY ENTIRELY

\section{A PLAY IN LETTERS}




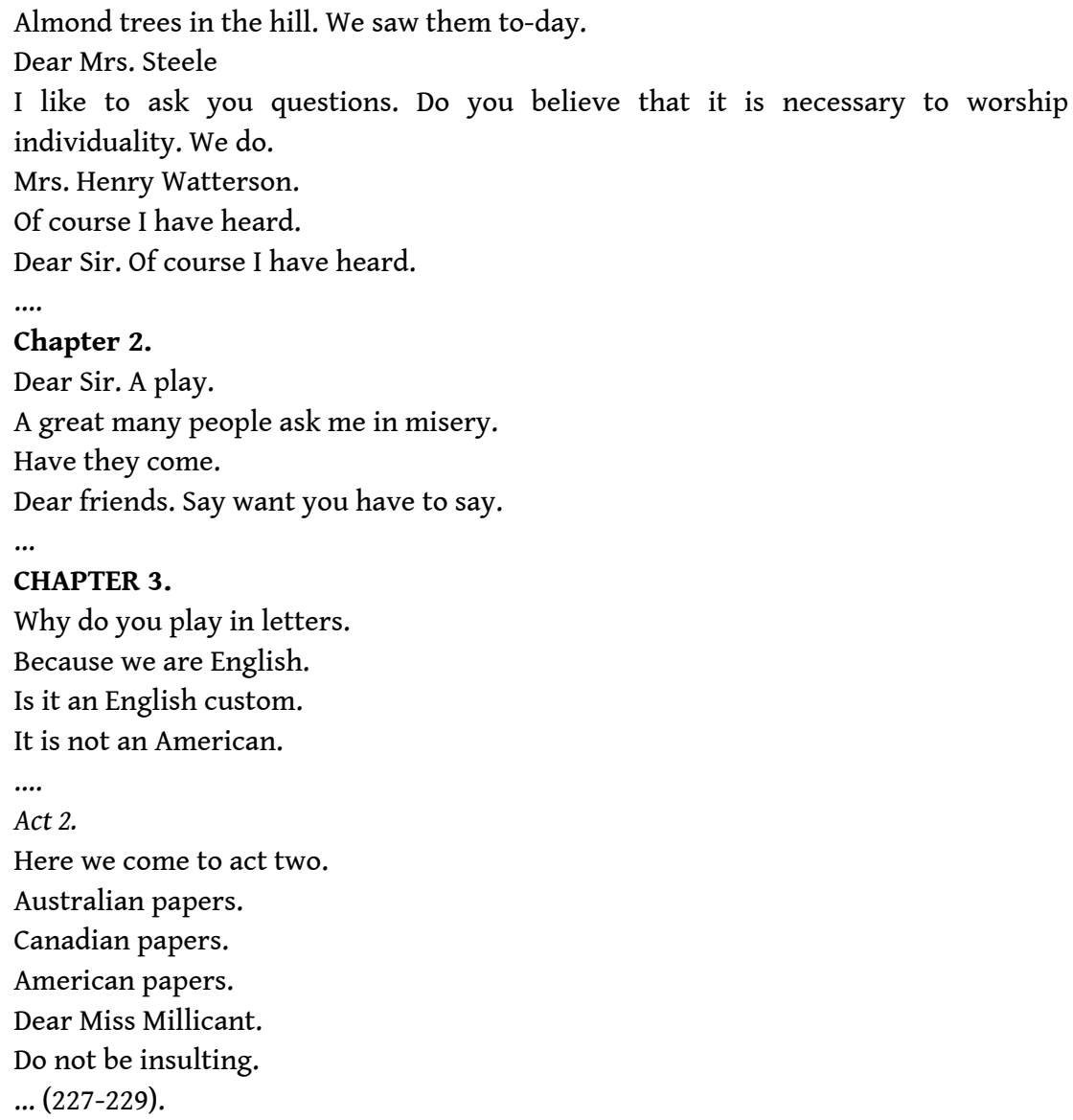

10 Ce mélange des matériaux, cet effet de collage, rappelle les compositions picturales cubistes. La distribution de la parole n'est pas annoncée par des didascalies et les personnages laissent place à des voix anonymes qui s'entremêlent participant ainsi à l'élaboration d'une écriture « cubiste ».

\section{Écriture picturale}

11 Dans The Autobiography of Alice B. Toklas puis, plus tard, dans « Transatlantic Interview » traduit en français par Marc Dachy, Stein rend compte de l'influence que des peintres cubistes comme Picasso ou Cézanne ont eu sur son écriture. ${ }^{9}$ L'analogie entre l'écriture de Stein et la peinture cubiste a ensuite souvent été reprise par les critiques comme récemment par Linda Voris :

Of course, Stein was the first to suggest painterly analogies to her work and from its earliest reception critics have followed suit, suggest comparison to Cubism in particular, and to the innovation of painters she admired such as Cézanne. "Stein's sense of landscape seems more painterly than theatrical," Lyn Hejinian has observed. Jane Palatini Bowers claims that the painterly analogy for playwriting freed Stein from the linear sequencing of narrative and gave her a model for treating words of the play as material and visual objects that occupy space with the simultaneity associated with Painting (Voris « Interpreting Cézanne » 74).

La rupture avec la mimesis évoquée plus haut et la multiplication des points de vue propre aux cubistes va de pair avec l'abandon de ce que Voris nomme «linear sequencing of narrative", à savoir l'abandon d'une construction narrative traditionnelle (délimitée à l'image de l'espace géographique). Dans sa quête de 
nouveauté (quête au cœur même du modernisme), Stein "désamorce", comme le rappelle Maria Clara Guiramaes Ferrer Carrilho, «tous les préceptes clés qui furent retenus de la théorie théâtrale aristotélicienne, en appelant de ses vœux une dramaticité détachée du muthos » (116). L'action n'est plus une histoire puisque, pour l'auteure, «tout ce qui n'[est] pas une histoire a le potentiel d'une pièce » (traduction de l'auteur, "Plays » 75, 73). ${ }^{10}$ Au déploiement conventionnel d'une intrigue, Stein préfère la stase, l'immobilité, une valeur qu'elle associe aussi au paysage. Lors de son discours " Play ", Gertrude Stein explique : "A landscape does not move nothing really moves in a landscape but things are there, and I put into the play the things that are there » (80). ${ }^{11}$ " A Curtain Raiser ", la plus courte proposition dramatique de Geography and Plays fait état de cette immobilité de l'action chère à Stein :

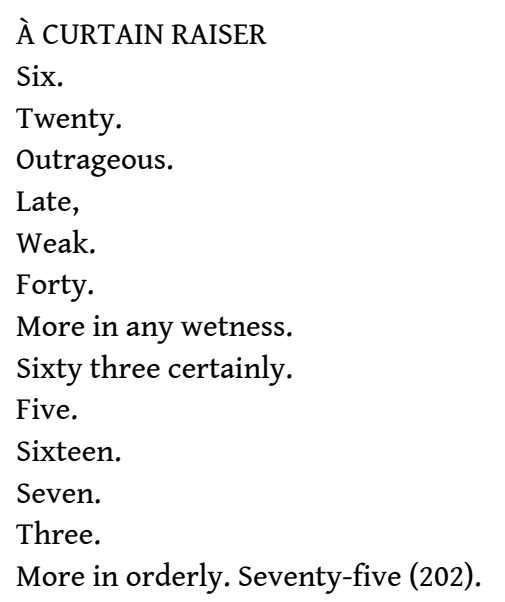

13 Le rideau se lève sur une succession de tableaux. Les noms et les adjectifs prédominent dans cette pièce; les verbes moteurs de la mise en action ont disparu : une impression de stase est alors créée. Sur la page et dans l'air (lors du passage à l'oral) les chiffres s'égrènent isolément comme encadrés par des silences matérialisés par les espaces typographiques et formant alors une série de tableaux. Cette impression de tableaux façonnés par le temps, c'est-à-dire les pauses, les silences, est reprise par Linda Voris pour qui Lend a Hand or Four Religions est une "pièce-paysage " composée de tableaux vivants contenus dans différents cadres :

Shifting to the spatial dimension of the text, Stein attempts to block the temporal unfolding that ordinarily accompanies sequences or succession. While scenes or passages that form through reiteration would appear to "take time," each scene seems to unfold and take shape in a single, self-contained frame. Following Stein's observations about the stillness of landscape, Lyn Hejinian has likened the arrested motion of landscape to a tableau vivant: "In essence the landscape, by virtue of its own laws, is transformed under attention into a tableau, a tableau vivant; episodes become qualities” («Interpreting Cézanne » 83).

14 Cet effet de cadrage temporel mais également visuel (puisque le cadrage est aussi une question de point de vue) nous amène à conclure que le paysage-drame dans les œuvres de jeunesse de Stein serait le drame de la contemplation : l'action chez Gertrude Stein consiste à représenter ce qui est vu dans son immobilité afin de faire partager aux spectateurs l'expérience du moment. Au-delà de l'image, le paysage chez Stein est donc aussi une temporalité vécue et partagée.

Pour Voris, la qualité picturale de l'œuvre de Stein tient également à son usage des mots comme " objets matériels et visuels ", pour revenir à la citation précédente. Les mots deviennent en effet des objets de composition graphique chez Stein. Dans 
"Plays », l'auteure, qui revient sur l'analogie paysage-pièce, insiste sur les mises en relation entre les éléments qui structurent le paysage et l'œuvre dramatique :

The landscape not moving but being always in relation, the trees to the hills the

hills to the fields the trees to each other any piece of it to any sky ... (« Plays » 81).

Les extraits des pièces cités illustrent cette mise en relation graphique entre les mots qui, s'ils ne sont pas syntaxiquement ou sémantiquement en relation ce qui crée une abstraction de fond, s'organisent sur la page et dans l'air pour créer des paysages, des «lang-scapes » selon les termes de Bowers, aux hauts ou bas-reliefs en fonction de la profondeur des blancs, de la longueur des pauses, des télescopages typographiques (majuscules, minuscules...), des alinéas. Dans "They Watch Me As They Watch This»: Gertrude Stein's Metadrama, Jane P. Bowers écrit :

Stein's plays are not in themselves landscapes ... they are like landscapes. The similitude lies in Stein's use of language ... Stein treats her words as though they are material objects related to each other spatially, that is, visually on the page and sonorously in the air. Her language assumes a materiality equal in presence to the materiality of the other elements of the performance events (122).

De par la physicalité de ses textes, les mots chez Stein sont acteurs (" performers ») du paysage dramaturgique, de la composition cubiste paysagère des œuvres. ${ }^{12}$

\section{L'expérience des lieux}

Pour Stein, le propre du théâtre mimétique est la simultanéité des émotions sur scène et dans la salle, puisque, dans le théâtre traditionnel, les émotions du spectateur sont en adéquation avec l'action représentée: le spectateur d'une scène de violence réalistement représentée ressentira les mêmes émotions que le comédien qui vit la scène («Plays » 60). Cet effet miroir, ce partage simultané des sensations favorisé par les procédés d'identification entre le personnage et le spectateur, empêche donc toute mise à distance. La mise à distance chez Stein n'induit pas, comme elle pourrait l'induire chez Bertolt Brecht, l'aliénation émotionnelle du spectateur dont seul l'intellect serait sollicité. ${ }^{13}$ Pour l'auteure américaine, le théâtre est d'abord une expérience sensorielle. La mise à distance chez Stein est rythmique : le spectateur n'est pas sur le même temps que l'action et réagit donc en décalé. L'expérience de ce qu'Adam Frank définit comme le "déphasage émotif» (Frank 113), créé par la syncope rythmique entre le «temps » de l'action (le «là-bas ») et le «temps » de réaction chez l'auditeur (le « ici »), fait naître chez le récepteur un sentiment de trouble. Stein écrit :

The thing that is fundamental about plays is that the scene as depicted on the stage is more often than not one might say it is almost always in syncopated time in relation to the emotion of anybody in the audience.

What this says is this.

Your sensation as one in the audience in relation to the play played before your sensation I say your emotion concerning that play is always either behind or ahead of the play at which you are looking and to which you are listening. So your emotion as a member of the audience is never going on at the same time as the action of the play.

This thing that fact that your emotional time as an audience is not the same as the emotional time of the play is what makes one endlessly troubles about a play, because not only is there a thing to know as to why this is so but also there is a thing to know why perhaps it does not need to be so («Plays» 58). 

également produits par la multiplication des points de vue engendrée par ces paysages cubistes que, selon Jean-Pierre Sarrazac, le « spectateur aurait seul le pouvoir à mettre en mouvement" (Poétique du drame moderne 102). Aux points de vue fictionnels à l'origine du drame, de l'action, s'ajoute le point de vue du spectateur qui est amené à penser un chemin, son chemin, pour configurer son propre paysage alors mis en mouvement par la succession des choix de perspective opérés au cours de la pièce. Dans son entrée sur la " pièce-paysage », Joseph Danan paraphrasant la démarche de Stein écrit :

Le propre du paysage, dit [Stein], est d'« être là ». Immobile sous nos yeux. Et j'entends que c'est moi, lecteur ou spectateur, qui crée le mouvement à l'intérieur du paysage, et qui relie les éléments en présence puisque tout est disposé là pour moi-à ma disposition (156).

Le spectateur devient paysagiste, acteur dans le processus artistique. Les paysages sont alors aussi variés que le nombre de spectateurs puisque chaque auditeur observera l'action via le prisme de sa subjectivité. Dans Everybody's Autobiography, Stein écrit: "whenever I write a play it is a play because it is a thing I do not see but it is a thing that someone can see that is what makes a play to me » (89). En déléguant au spectateur le pouvoir de créer des images qui lui sont propres, Stein donne à ses écrits une théâtralité pleine. Théâtre vient du grec « regarder », « contempler ». C'est le regard du spectateur qui fait donc théâtre dans les œuvres de Stein. Théatre de la contemplation, le théâtre de Stein est ainsi un "théâtre de l'intime » dans le sens de "théâtre de la psyché du [sujet -] personnage, » comme le définit Sarrazac, mais également dans le sens de «théâtre de la psyché du sujet-spectateur » qui voit ce qu'il ou elle souhaite, consciemment ou pas, voir. ${ }^{14}$

21 Pièces kaléidoscopiques, aux multiples visages et paysages selon les points de vue adoptés, les œuvres dramatiques de Stein sont donc plurielles dans leur singularité. Les drames paysages de Gertrude Stein mettant en scène une individualisation du regard sont à l'image de ce que Michel Collot définit comme la " pensée paysage ». L'auteure capte le genius loci, l'esprit du lieu, c'est-à-dire, chez Stein, l'ici et maintenant de l'expérience vécus par les subjectivités plurielles qu'elle met en scène. Plus que des images, comme nous l'avons vu, le paysage est en effet chez l'artiste une stase, un temps suspendu qui est alors saisi par le génie de l'écriture steinienne dans la totalité quasi-synesthésique du moment. Stein embarque ses lecteurs par-delà le paysage et nous offre des paysages que nous sommes amenés à nous approprier pour vivre notre propre expérience dans la singularité de notre ici et maintenant. La multiplication des points de vue transcrits sensoriellement sur la page est donc encore démultipliée lors du passage de la réception par les lecteurs-spectateurs qui refaçonnent la mosaïque de paysages à leur manière.

Rendre compte de cette pluralité lors du passage de la page à la scène est, pour les metteurs en scène, un défi qu'aucun ne s'est hasardé à relever du vivant de l'auteure qui pourtant, comme elle l'expliquait à son amie Mabel Dodge, souhaitait avant tout voir jouer ses pièces et c'est la raison pour laquelle elle hésita à les publier (Ryan 165-168). Le lecteur des pièces de Geography and Plays a donc, du vivant de Stein, été condamné à rester au stade du "devenir-spectateur », un spectateur en puissance qui n'aura pu voir sur scène la concrétisation des paysages steiniens. Depuis la disparition de Gertrude Stein, quelques metteurs en scène se sont essayés à l'adaptation de 
certaines des œuvres du recueil mais les tentatives restent, semble-t-il, timides. $\mathrm{Si}$, comme Lehmann l'écrit, Stein était précurseur du théâtre contemporain postdramatique, nous pourrions nous demander si, à l'heure de l'interdisciplinarité artistique, les nouvelles technologies pourraient être des outils permettant de non seulement rendre compte de la dimension cubiste des œuvres mais également d'individualiser le parcours du spectateur qui deviendrait acteur de son propre voyage.

\section{BIBLIOGRAPHIE}

Alfandary, Isabelle. "Page-Landscapes in the Theatre of Gertrude Stein." Reflective Landscapes of the Anglophone Countries. Ed. Pascale Guibert. Amsterdam : Rodopi, 2011. 257-270.

---. "Voix et responsabilité dans le théâtre de Gertrude Stein." Tropismes [En ligne], 0.17 (2011) : 1-10. Web. 20 dec. 2016. URL : http://ojs.u-paris10.fr/index.php/tropismes/article/view/115.

Bowers, Jane P. “They Watch Me As They Watch This”: Gertrude Stein's Metadrama. Philadelphia: University of Pennsylvania press, 1991.

Chassay, Jean-François, et Eric Giraud. Contemporanéités de Gertrude Stein. Paris : Editions des archives contemporaines, 2011.

Chaudhuri, Una. Staging Place: The Geography of Modern Drama. Ann Arbor: University of Michigan Press, 1997.

Collot, Michel. « D’une modernité plurielle ». In Paysage et modernité(s). Eds. Aline Bergé et Michel Collot. Bruxelles : OUSIA, 2007. 15-27.

---. La Poésie moderne et la structure d'horizon. Paris : P. U.F, 2014.

---. « La pensée-paysage ». In Le Paysage : état des lieux. Eds. Françoise Chenet ; Michel Collot ; Baldine Saint Girons. Bruxelles : OUSIA, 2001. 498-511.

---. La Pensée-paysage. Arles : Acte Sud, 2011.

---. La Matière-émotion. Paris : P.U.F., 1997.

---, et Françoise Chenet ; Baldine Saint Girons (eds.). Le Paysage : état des lieux. Bruxelles : OUSIA, 2001.

---, et Aline Bergé (eds.). Paysage et modernité(s). Bruxelles : OUSIA, 2007.

---, et Augustin Berque (eds.). Les Enjeux du paysage. Bruxelles : OUSIA, 1997.

Côté, Jean-François. « Gertrude Stein dramaturge : un théâtre pour personne. » In Contemporanéités de Gertrude Stein. Eds. Jean-François Chassay, Éric Giraud. Paris, Éditions des archives contemporaines, 2011. 101-112.

Danan, Joseph. « Pièce-paysage ». In Lexique du drame moderne et contemporain. Jean-Pierre Sarrazac, ed. Belval : Circé, 2005. 156-158.

---. Qu'est-ce que la dramaturgie? Arles : Actes Sud, 2010. 
Dickie, Margaret. Stein, Bishop \& Rich: Lyrics of Love, War \& Place. Chapel Hill: University of North Carolina Press, 1997.

Frank, Adam. "Radio Free Stein. Rendering Queen and Country." In Primary Stein. Returning to the Writing of Gertrude Stein. Janet Boyd and Sharon J. Kirsch, eds. Plymouth: Lexington Books, 2014. 145-162.

---. « Gertrude Stein et la question du théâtre ». In Contemporanéités de Gertrude Stein. Eds. Chassay, Jean-François, et Eric Giraud. Paris : Editions des archives contemporaines, 2011. 113-121. Guiramaes Ferrer Carrilho, Maria Clara, « Devenir-Paysage de la scène contemporaine. Le dépaysement du drame ». Thèse soutenue le 9 dec. 2014, Paris 3.

Jouve, Emeline. « Entretien avec Lise Avignon et Emma Morin, Gertrude Stein au théâtre : Le monde est rond (G. Stein, L. Avignon) ; Listen to Me (G. Stein, E. Morin) », Miranda [Online], 13 (2016). Web. 20 dec. 2016. URL: http://miranda.revues.org/9482

---. “Geography and Plays: Spaces in Gertrude Stein's Early Plays (1913-1919)." South Atlantic Review 76.4 (2014): 101-116.

---. “Gertrude Stein's Historic Drama (1930). Dismembering the Past; Remembering the Present." Sillages Critiques, à paraître.

Lehmann, Hans-Thies. Le théâtre post-dramatique. Trad. Philippe-Henri Ledru, Paris : l'Arche, 2002. Naugrette, Catherine. Paysages Dévastés : Le Théâtre Et Le Sens De L'humain. Belval : Circé, 2004.

Palatini Bower, Jane. “The Composition That All the World Can See: Gertrude Stein's Theater Landscape." In Land/Scape/Theater. Elinor Fuchs and Una Chaudhuri, eds. Ann Arbor: University of Michigan Press, 2002. 121-141.

Ryan, Betsy A. Gertrude Stein's Theatre of the Absolute. Ann Arbor, Mich: UMI Research Press, 1984.

Ryan, Judith. The Vanishing Subject. Early Psychology and Literary Modernism. Chicago: The University of Chicago Press, 1991.

Savinel, Christine. Gertrude Stein. Autobiographies intempestives. Paris : Editions Rue d'Ulm, 2017.

Sarrazac, Jean-Pierre. Poétique du drame moderne : de Henrik Ibsen à Bernard-Marie Koltès. Paris : Éditions du Seuil, 2012.

-------. Théâtres intimes. Arles : Actes Sud, 1989.

Stein, Gertrude. “Accent in Alsace. A Reasonable Tragedy.” In Geography and Plays. Gertrude Stein. Madison: U of Wisconsin P, 1993. 409-415.

---. “Americans.” Geography and Plays. In Gertrude Stein. Madison: U of Wisconsin P, 1993. 39-45.

---. The Autobiography of Alice B. Toklas, New York: Vintage, 1990.

---. “Bonne Annee. A Play.” In Geography and Plays. Gertrude Stein. Madison: U of Wisconsin P, 1993. 302-303.

---. “Captain Walter Arnold. A Play.” In Geography and Plays. Gertrude Stein. Madison: U of Wisconsin P, 1993. 260-261.

---. “Counting her Dresses. A Play.” In Geography and Plays. Gertrude Stein. Madison: U of Wisconsin P, 1993. 275-285.

---. "Do Let Us Go Away. A Play." In Geography and Plays. Gertrude Stein. Madison: U of Wisconsin $P, 1993.215-226$. 
---. “Every Afternoon. A Dialogue.” In Geography and Plays. Gertrude Stein. Madison: U of Wisconsin P, 1993. 254-2459.

---. Everybody's Autobiography. New York: Random House, 1937. Print

---. "For the Country Entirely. A Play in Letters." In Geography and Plays. Gertrude Stein.

Madison: U of Wisconsin P, 1993. 227-238.

---. Four in America. New Haven: Yale UP, 1947.

---. “He Said It. Monologue." In Geography and Plays. Gertrude Stein. Madison: U of

Wisconsin P, 1993. 267-274.

---. “IIIIIIIII” (1913), “A Curtain Raiser." In Geography and Plays. Gertrude Stein. Madison: U of Wisconsin P, 1993. 189-198.

---. “I Like It to Be a Play. A Play." In Geography and Plays. Gertrude Stein. Madison: U of Wisconsin P, 1993. 286-289.

---. “The King or Something (The Public is Invited to Dance).” In Geography and Plays.

Gertrude Stein. Madison: U of Wisconsin P, 1993. 122-133.

---. “Ladies Voices (Curtain Raiser)." In Geography and Plays. Gertrude Stein. Madison: U of Wisconsin P, 1993. 203-204.

---. “Mexico. A Play.” In Geography and Plays. Gertrude Stein. Madison: U of Wisconsin P, 1993. 304-330.

---. “Not Sightly. A Play.” In Geography and Plays. Gertrude Stein. Madison: U of Wisconsin P, 1993. 290-301.

---. "One Van Vechten." In Geography and Plays. Gertrude Stein. Madison: U of Wisconsin P, 1993. 199-200.

---. "Plays." Look at Me Now and Here I Am. Selected Works 1911-145. Ed. Patricia Meyerowitz. Chester Spring: Peter Owen, 1967. 58-81.

---. “Please Do Not Suffer. A Play." In Geography and Plays. Gertrude Stein. Madison: U of Wisconsin P, 1993. 262-266

---. "Polybe in Port. A Curtain Raiser." In Geography and Plays. Gertrude Stein. Madison: U of Wisconsin P, 1993. 25.

---. “Turkey Bones and Eating and We Liked It. A Play.” In Geography and Plays. Gertrude Stein. Madison: U of Wisconsin P, 1993. 239-253.

---. Interview transatlantique. Trad. Marc Dachy. Paris: Transédition, 1987.

---. "What Happened. A Play in Five Acts.” In Geography and Plays. Gertrude Stein.Madison: U of Wisconsin P, 1993. 205-209.

---. "White Wines. Three Acts." In Geography and Plays. Gertrude Stein. Madison: U of Wisconsin P, 1993. 210-214.

---. “Composition as Explanation.” Look at Me Now and Here I Am. Selected Works 1911-145. Ed. Patricia Meyerowitz. Chester Spring: Peter Owen, 1967. 21-30.

Voris, Linda. The Composition of Sense in Gertrude Stein's Landscape Writing. Cham: Springer International Publishing, 2016. 
---. “Interpreting Cézanne: Immanence in Gertrude Stein's First Landscape Play, Lend a Hand or Four Religions." In Modernism/modernity, 19.1 (2012): 73-93.

\section{NOTES}

1. Les termes « drame » et «théâtre " sont employés pour référer respectivement au texte et à la représentation.

2. Dans son ouvrage Stein, Bishop, Rich. Lyrics of Love, War and Place, Margaret Dickie écrit : "[Stein] has been acclaimed for her experiments with time rather than place, for her interest in the 'continuous present' rather than for the way she ordered her world through geographical notations" (59). Dix ans après la publication de son ouvrage, quelques études prenant en considération la dimension spatiale de l'œuvre de Stein ont été menées. Parmi ces publications, nous pouvons citer deux volumes très récemment publiés: The Composition of Sense in Gertrude Stein's Landscape Writing par Linda Voris (2016) et Gertrude Stein: Autobiographies intempestives (voir le chapitre «L'Amérique : géographie du hors-temps » par Christine Savinel (2017)).

3. Selon la version originale : « a play [is] exactly like a landscape » (« Play » 75).

4. L'expression « image du site perçu » renvoie aux trois composantes définitoires de la notion de "paysage» selon Michel Collot: «la notion de paysage fait intervenir au moins trois composantes : un site, un regard, une image » (Pensée-Paysage 17).

5. Cyrena N. Pondrom rappelle que Geography and Plays est un recueil prototypique à bien des égards : " this volume is replete with firsts-her first portrait (at least by her own account), her first play, her first experiments with alogical writing that defies any form of adequate paraphrase » (Pondrom vii).

6. Cette étude s'inscrit dans la continuité du travail que j'ai mené dans «Geography and Plays: Spaces in Gertrude Stein's Early Plays (1913-1919) » qui s'intéresse à la notion spatiale en termes référentiels (du point de vue des lieux communs en littérature, des lieux diégétiques, du lieunation, et du lieu-théâtre). Le présent article recentre l'analyse sur les dimensions dramatiques et dramaturgiques de l'approche paysagère de Stein dans Geography and Plays.

7. Pour une analyse plus détaillée des effets créés par la multiplication des lieux, voir «Gertrude Stein's Poetics of Dislocation» dans «Geography and Plays : Spaces in Gertrude Stein's Early Play (1913-1919)» (Jouve 52-53).

8. Il est intéressant de rappeler ici que Gertrude Stein avait été élève de William James.

9. Dans The Autobiography of Alice B. Toklas, Stein établit un parallèle avec le cubisme et ses textes lorqu'elle considère « Manctha » comme une œuvre donc l'impact dans l'histoire de la littérature fut similaire à celui des tableaux de Picasso (et Matisse) dans l'histoire de la peinture (54). Dans Interview transatlantique, Stein revient au précurseur des cubistes, Cézanne : « Avant cette époque, la composition consistait en une idée centrale par rapport à laquelle tout autre élément était un accompagnement ou une adjonction, mais n'était pas une fin en soi, et Cézanne émit cette idée que dans la composition une chose est aussi importante qu'une autre chose. Chaque partie est aussi importante que le tout et cela m'impressionnait vivement (...). Vous voyez, j'essayais de développer l'idée de chaque partie de la composition comme étant aussi importante que le tout (...) vous voyez, il en faisait quelque chose comme une atmosphère et ce n'était pas seulement le réalisme des caractéristiques mais le réalisme de la composition qui était la chose la plus importante, le réalisme de la composition de mes intuitions. Après tout pour moi un être humain est aussi important qu'un autre être humain, et on peut dire qu'un paysage présente des valeurs égales, un brin d'herbe a la même valeur qu'un arbre » (111).

10. La version originale de la citation de Stein est: "anything that [was] not a story could be a play" ("Play", 73). 
11. Pour une étude de concept de l'être « là-bas " ("things that are there"), voir "Gertrude Stein's 'City of Words': Plays as Landscape» dans “Geography and Plays : Spaces in Gertrude Stein's Early Play (1913-1919)" (57-60).

12. Dans son projet Radio Free Stein, Adam Frank propose une mise en voix, musique et son de «For the Country Entirely » qui peut être appréciée en ligne sur le site radiofreestein.com. Frank explique dans son article « Radio Free Stein. Rendering Queen and Country » son travail de mise en paysage : «In my radio interpretation, I have chosen to record these 'landscape': actors speak [the] lines so as to create specific sonir effects outside the ongoing stream of dialogue » (150).

13. Les critiques ont souvent théorisé la stratégie d'aliénation de Brecht comme une technique permettant aux spectateurs de se mettre totalement à distance émotionnellement pour que seul l'intellect soit sollicité. Cette vue est réductive d'où mon emploi du conditionnel dans " pourrait l'induire ».

14. Dans Théâtres intimes, Jean-Pierre Sarrazac écrit: "Théâtres intimes dresse avant tout le constat d'un déplacement: le conflit dramatique qui se déroulait jadis dans un espace interpersonnel prend désormais pour siège principal la vie intérieure de chaque personnage créé par l'auteur; de Strindberg à Beckett et d'Ibsen à Duras, nous assistons non seulement à un glissement du drame vers plus de subjectivité mais encore à une 'insularisation' du drame dans la psyché du personnage » (10).

15. Nous pouvons noter le travail de Marc-Olivier Dupin et Elizabeth Lennard qui présentaient en 2002 «Accents en Alsace, » une adaptation convoquant plusieurs disciplines artistiques dont le théâtre, l'opéra (cher à Stein), la vidéo. Des extraits de captations de la représentation sont disponibles à l'adresse <https://vimeo.com/44882918> (23.02.17). En 2009, la metteuse en scène et comédienne Emma Morin créait Listen to $M e$, un spectacle pensé notamment autour de la lumière qui est un média à part entière de la création. Pour plus d'information sur Listen to Me, voir Emeline Jouve, «Entretien avec Lise Avignon et Emma Morin, Gertrude Stein au théatre : Le monde est rond (G. Stein, L. Avignon) ; Listen to Me (G. Stein, E. Morin) », Miranda [Online], 13 (2016), Web. 20 dec. 2016, URL : http://miranda.revues.org/9482.

\section{RÉSUMÉS}

En dépit de leur originalité formelle dans le canon moderniste, les œuvres dramatiques de Gertrude Stein restent peu connues. Cet article s'intéresse aux premières pièces de l'auteure qui sont alors abordées sous l'angle du paysage. Si pour Gertrude Stein, Lend a Hand or Four Religions, achevée en 1922, fut sa première "landscape play" ou "pièce paysage ", les pièces de Geography and Plays (écrites avant 1922 et la publication du volume) peuvent être considérées comme des prototypes du paysagisme dramatique steinien. Ces pièces se lisent comme des paysages intimes pluriels en cela qu'elles retranscrivent les subjectivités d'une auteure, de ses personnages fantasmatiques mais aussi des lectrices et lecteurs. Afin de rendre compte de cette subjectivité, nous reviendrons sur l'emploi des termes «géographie» et "paysage » par Stein avant de considérer les ressorts de l'écriture picturale steinienne. Enfin, l'agentivité des lecteursspectateurs sera abordée.

In spite of the originality of Gertrude Stein's modernist plays, her dramatic work remains largely unknown. This paper focuses on the writer's early plays which are considered from the perspective of the landscape. If Stein considers her 1922 play Lend a Hand or Four Religions, as her 
first "landscape play", the plays from Geography and Plays (written before 1922 and the publication of the volume) can be seen as prototypes of Stein's dramatic landscaping. These plays can be read as landscapes of the intimate in that they translate the subjectivity of a writer, of her phantasmatic characters, and also of her readers. To demonstrate that subjectivity is prevailing in Stein's works, the use of the terms "geography" and "landscape" will be studied, before focusing on Stein's pictorial writing. Finally, the focus will be on the agency of the readersspectators.

\section{INDEX}

Mots-clés : cubisme, espace, expérience, géographie, lecteur-spectateur, modernisme, moment, paysage, sensation, subjectivité, théâtre

Keywords : cubism, experience, geography, landscape, modernism, moment, reader-spectator, sensation, space, subjectivity, theatre

\section{AUTEURS}

\section{EMELINE JOUVE}

Maître de conférences

INU Champollion/Université Toulouse Jean-Jaurès

Emeline.jouve@univ-jfc.fr 